\title{
PREVENTION OF MENTAL VIOLENCE IN THE SYSTEM OF PROVIDING INFORMATION SECURITY OF CITIZENS IN UKRAINE
}

\begin{abstract}
Ganna Sobko ${ }^{1}$, Olena Mitina ${ }^{2}$

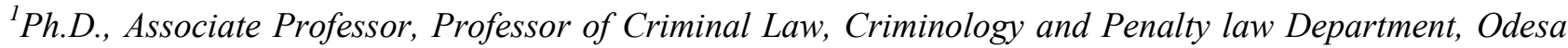
State University of Internal Affairs, Odesa, Ukraine, e-mail: sobkoganna1984@ukr.net, ORCID: https://orcid.org/0000-0002-5938-3400

${ }^{2}$ Ph.D., Associate Professor, Department of English Philology and Translation Studies, Odessa National Polytechnic University, Odessa, Ukraine, e-mail: olenamitina@ukr.net, ORCID: https://orcid.org/00000001-8732-2421
\end{abstract}

The relevance of the chosen theme is because of the development of new technologies and the global Internet sharply determine the issues of information security. Given the availability of sources of information, free movement of information flows, in particular, and negative content facilitates the possibility of committing offenses by affecting the psyche of people without real contact, which creates modern threats to psychological security and is a problem of modern mental violence against people.

Preservation of information sovereignty, the realization of constitutional rights of citizens, society, and the state to information is an urgent problem in Ukraine. This issue has become especially important in the context of constantly growing international conflicts, which are accompanied by information and psychological influences on the minds of Ukrainian citizens, which further affects the information security of Ukraine through the commission of criminal offenses.

In the current scientific environment, much attention is paid to the study of information security of the state, both by domestic and foreign researchers, among whom a significant contribution was made by Z.K. Brzezinski [1], V.O. Bondarenko [2], O.G. Gnatsov [3], Yu. O. Gorban [4], O.P. Dzoban [5], B.A. Kormich [6], E.A. Makarenko [7], R.R. Marutyan [8], F.M. Medved [9], V.M. Petrik [10], V.G. Pilipchuk [11], O.L. Samorukova [12], V.B. Tolubka [13] and others. The issue of human information security was studied by scientists: O.L. Gapeeva [14], O.S. Zozulya [15], O.V. Sosina [16], and others.

The State of Ukraine has established in the Constitution that the protection of information security is one of the most important functions of the state, the matter of Ukrainian people (Article 17 of the Constitution of Ukraine) [17].

Besides, the legal basis for the protection of information security of citizens of Ukraine is the Law of Ukraine "On Information" [18], the Law of Ukraine "On Printed Media" [19], "On Television and Radio" [20], "On Information Protection in Automated Systems" "[21], Decree of the President of Ukraine" On the Doctrine of Information Security of Ukraine " from 07/08/2019, № 514/2009 [22]. 
Society and the state now face the issue of restricting or prohibiting the circulation of information harmful to society, given that information in a given situation may be the subject of illegal actions.

Depending on the type of information threats, there is information security of the individual, society, and the state.

Informative and psychological security of a person and information security of the state are similar in terms of legal and organizational regulation, but information security of the state "serves" public relations regarding the creation, dissemination, storage, and consumption of information, while information and psychological security of the individual information on people's consciousness, not the degree of its security or access to information.

That is, the subject of research of information and psychological security of citizens is the influence of certain subjects of creation and dissemination of information on human psyche, manipulation of people's consciousness as a result of such activities, which further creates preconditions for citizens to commit criminal offenses.

Information and psychological security of citizens is a state of protection of human psyche from various information determinants of influence, which creates obstacles to the formation and functioning of an adequate information-oriented basis of social behavior of a person in modern society $[23,19]$.

Influencing factors that endanger the vital interests of citizens are:

- providing poor quality information (misinformation, false, untrue);

- the influence of outsiders on information and its resources and their formation, as a consequence of informing citizens of one-sided information;

-the threat to the rights and freedoms of citizens to information (the right to privacy; the right to protection of honor and dignity, etc.) [25; 24].

The problem related to the media influence on the provision of low-quality, unverified or distorted information and the influence of third parties on the way of conveying information to the citizens of Ukraine through the media remains important.

As a social institution, the media actively use their potential to influence the way of life of people and ways of their integrative behavior. The media have taken their place in the daily life of modern person, firmly entrenched in it. If we talk about young people, today it is difficult to find a person who can refuse the presence of television and especially the Internet in his/her life. Watching the news, advertising, entertainment, and shows, TV series, as well as horoscopes, weather forecasts, etc. are firmly entrenched in our lives, and a person is unaware of the impact that this process has on the formation of his/her life attitudes, behavioral stereotypes, habits, everything of what constitutes our daily life. 
One cannot disagree with L.M. Rybakova, who claims that without state support the spiritual basis of society is formed by the media, which are subject to the founders, who use information broadcasting to broadcast their own limited (social status, worldview, personal experience, the responsibility to sponsors, etc.) values. As a result, she writes, we have a crowd of "stars" and "style icons" that demonstrate a personal level of consumption - cars, clothes, accessories, other people's services. It seems that the spiritual "staples" of society are formed and dictated by the glamorous community: overseas villa, foreign educational institutions, foreign shopping, songs in a foreign language, Hollywood "style icons" and cult works, foreign sex symbols, and more. [25, 234]. Of course, we cannot talk only about the negative impact of the media on the life way, the formation of habits and values of young people, because this would be a one-sided approach to the current problem. The media exert a social, cultural, psychological influence on society, shaping the needs of people, and these needs are not always related to the possession of material goods (although we do not rule this out). These may be needs aimed at human self-development, self-education (for example, a large number of educational lectures on the Internet), raising the cultural level (channel "Culture"), the formation of attitudes to a healthy lifestyle, motivation to achieve goals. The media is the main source of information, and today also the main means of communication, so they traditionally perform important social functions, including communication, education, broadcasting, and socializing.

But the question arises as to whether these needs are met by the media, and whether their impact is so great directly on the young person's personality and its important life institutions? After all, even in the era of censorship on radio and television, negative trends in the lifestyle of young people were present, so not everything was so cloudless. Therefore, noting the positive impact of the media, and especially the Internet, on young people, it is necessary to first analyze the negative impact they have on the majority of young generation. Under the influence of the media, children and adolescents develop aggression. And the most aggressive are computer games and modern cinema. However, mostly negative feelings and attitudes towards people of other nationalities, which is a serious problem for the polyethnic society of Ukraine and can be one of the causes of conflicts in the youth environment [26, 167-168].

The resources of the media have great potential for manipulating the human consciousness of a generation of young people and influencing the ways of shaping their way of life. Will P.A. Sorokin listed "aspects of human behavior" that "exhaust the whole way of person's life" [27, 15]. And today sociologists, using the term "way of life", mean a set of forms of individual behavior, his/her activity in the production sphere, everyday life, areas of social, political, cultural, and scientific and scientific spheres, as well as meeting social and individual needs. All these forms of behavior 
are formed under the influence, on the one hand, socio-economic and political conditions, and on the other hand, they play a significant role in mentality, traditions, customs, identity. Based on a large number of factors influencing the formation of lifestyle, this definition can be understood as both conscious and spontaneous development of life-based on values, worldviews, mentality, etc., as well as under the influence of external factors in the era of an information civilization. mass media. Today, they have a decisive influence on behavior stereotypes, strategies, and attitudes of younger generation.

The uncontrolled Internet contains threats to users, especially children, and youth, associated with the spread of aggressive content $[28,86]$. The negative role of the growing influence of social networks on young people cannot be ignored, the story of Varvara Karaulova and others clearly shows the negative consequences of "living online" [29]. This should be the subject of careful study to prevent or minimize adverse effects. The results of the research show that the formation of image and lifestyle of young people is influenced by the media, which, unfortunately, often hurt the consciousness and behavior of young people. This is manifested in the fact that the media today do not form a stable systematic view of young people about values. The picture of the world formed by them is fragmentary and is mediated by the political and economic forces behind them with little state involvement.

It can be concluded that the way of life of young people is formed under the influence of modern media, the analysis of which shows the fragmentary and unsystematic of their policy of forming values, or rather its absence. Characteristics of the present time are the lack of use of modern information channels by state bodies to form youth loyalty to Ukrainian values, education, and strengthening of universal values, development of an active civic position, which forms in young people a positive lifestyle.

Information security is very important in ensuring the rights, freedoms, and interests of citizens, especially in modern Ukraine, because the use of the latest information technologies has flooded all spheres of people's lives and includes, on the one hand, quality information and unimpeded access. to information sources, on the other one- ensuring the confidentiality of information (defined by information with limited access), strengthening the integrity of society, including the prevention of negative information influences and more.

It should be noted that such a weapon as information is quite effective, and the question of its power has been considered for a long time, for example, G. Schiller determined that the state, which seeks to dominate, should control the media [30, $111]$.

Based on the legal certainty of the media activities, it is possible to consider the media as the "fourth power", because the importance of the media impresses the trust 
of the population. Currently, the situation is such that citizens trust the media much more than public authorities [31,154].

To interpret social events, citizens usually use the information and concepts that the media are activated in their minds [5, p. 71].

Ukraine has a fairly extensive media system, which in turn creates an information flow to reflect different views of the political situation, each media outlet promotes its vision of the political situation, including paying close attention to the negative work of law enforcement and criticism of political leaders and political parties. including to order, etc.

During the exercise of informational influence on moral and political discrediting of law enforcement agencies, public authorities through the media, society open up the possibility of higher tolerance for criminal offenses. In cases where the media partially or completely discredit law enforcement activities by information attacks, the latter loses its legitimacy $[32,196]$.

It is necessary to note the diverse propaganda of the mass media in Ukraine when each region was under various informational influences, which is confirmed by the results of social survey in the spring of 2014 [684].

According to the results of the survey, as of 2014, Inter and Ukraine TV channels were the most popular in the South and East of the country, with an audience of over $60 \%$ of viewers, but in Western Ukraine, this percentage was only $10-15 \%$ of viewers. About $78 \%$ of viewers in the South and East became viewers of Russian TV channels, namely political news.

At the same time, viewers of Central and Western Ukraine preferred such channels as Channel 5 (66\% of viewers), TVi (78\% of viewers), Gromadske.TV (89\% of viewers), Espresso.TV (94\% of viewers).

According to the results of this social survey, citizens in the regions of Ukraine formed a diverse attitude to political events, the most positive attitude to the revolutionary events were citizens - viewers of Public Television (85\% who fully or mainly supported the Revolution), Espresso.TV (79\% support), TVi (70\% support), Channel 5 (61\% support), ie citizens of Central and Western Ukraine.

At the same time, TV viewers - Inter, Ukraine ( $61 \%$ of TV viewers did not support the revolution) - citizens of the South and East of Ukraine - had a negative attitude to the revolutionary events.

According to the author, such a difference in views and attitudes was formed due to the commercialization of the media and the focus on profit, as well as dependence on the owner, which led to a lack of objective information about the state of events (isolation from independent media, information and psychological pressure on population from propaganda sources of information, seizure of strategic objects of telecommunication infrastructure in the Autonomous Republic of Crimea, Donetsk 
and Luhansk oblasts), which formed alarming political sentiments and further incited hostility and separatist sentiments among the population.

Round-the-clock news from the scene, information on the number of dead, prisoners and coverage of the political situation from a subjective point of view, through systematic repetitions, suggestion deprived of the opportunity to obtain reliable objective information, for example, on the channel "1 + 1" every 15-60 minutes J. Bodiyar noted that "repetition is a figure of rhetoric that deserves attention because it is through repetition that the idea is firmly established that in the end it is perceived as an unalterable truth" [33, 155].

According to the author, in the above situation, the media used psychological influence on citizens: manipulation of consciousness, which can be defined as mental violence, because, as a result of such influence, anxiety increased and there was no possibility to objectively determine their attitude to the political situation in the country. and prioritization. At the same time, it should be noted that all the events that took place on the territory of Ukraine are not the result of the activities and influence on the minds of people only of the media, but their participation can not be ignored.

In turn, it is important to pay attention to criminal offenses against the foundations of national security, of which terrorist criminal offenses were not of nature for Ukraine until 2014. According to statistics, in the period from 2001 to 2013 in the proceedings of the SBU investigators were only 57 criminal proceedings, on the grounds of criminal offenses under Art. $258^{1}$ of the Criminal Code of Ukraine, among them - only 14 proceedings were sent to the court with indictments [34].

However, for the period from 2014 to the first half of 2016 for committing a criminal offense under Art. $258^{1}$ - of the Criminal Code of Ukraine (concerning calls to commit, preparation, financing) was found guilty of committing crimes against the state and the Ukrainian people, with different sentences of approximately 226 persons sentenced to different terms of imprisonment, according to with data published by the SBU.

Based on the practice of convictions, since 2014, the number of criminal offenses has increased, where the object of criminal offense is the national security of Ukraine, namely criminal offenses aimed at forcible change or overthrow of the constitutional order and public appeals to such (Article 109 of the Criminal Code), encroachment on the territorial integrity and inviolability of Ukraine, including public appeals or dissemination of materials calling for such actions (Article 110 of the Criminal Code of Ukraine) and terrorism (258 ${ }^{1}$-of the Criminal Code of Ukraine).

Criminal offenses against the foundations of national security were mostly committed through social networks (Vkontakte, Odnoklassniki, less often Facebook), 
where subjects posted calls for a violent change of the constitutional order and for the seizure of state power (for example, case № 398/5891 / 14-k, № 308/8797/14-k, № 404/6035/14-k, № 667/5040/15-k), however, there were cases with calls to hold rallies to assist in the DPR and LPR activities (for example, case № 668/13682/14-k).

Given the "Generalization of statistical and analytical data on the activities of the prosecutor's office in 2018", it should be noted that in Ukraine continues to increase the number of reported criminal offenses against the national security of Ukraine, the greatest dynamics was registered in Poltava, Luhansk, Kyiv, Kherson, Dniprovshchyna, Odesa and Kharkiv regions and in Kyiv.

At the same time, every third criminal offense is an encroachment on the territorial integrity and inviolability of Ukraine and treason. The number of criminal offenses aimed at forcible change or overthrow of the constitutional order or seizure of state power has also increased.

With such statistics, the increase in crimes against the foundations of national security, criminal offenses of a terrorist nature has decreased, except in Donetsk and Luhansk regions, which is due to Operation Joint Forces there [35].

This applies to criminal offenses against the foundations of national security. However, it should be noted in the context of information security of citizens that in Ukraine recently gained momentum information criminal offenses committed through theft or destruction of information, for selfish or hooligan motives.

Even though Ukraine ratified the Convention on Cybercrime in 2005 (№ 185 of 23 November 2001), there was no effective and efficient mechanism to combat this type of criminal offense.

According to Section XVI of the Criminal Code of Ukraine, the main cybercrimes include the distribution of malicious software, fraud, credit card theft, and password cracking, including with the help of - Phishing (access to confidential user data), posting false (illegal) information on the Internet, as well as infringement of copyright and related rights.

Since 2015, the number of cybercrimes has doubled, as a result of which Ukraine has begun an active fight against information criminal offenses.

For example, as of 2015 on the grounds of criminal offenses under Art. 361 of the Criminal Code of Ukraine, 432 criminal proceedings were initiated, and in 2017 195 proceedings; on the grounds of a criminal offense under Art. 362 of the Criminal Code of Ukraine in 2015, 75 criminal proceedings were initiated, while in 2018 1070 such proceedings. In 2017, there was a high jump in the number of criminal offenses in the field of information security, namely after the cyber attack of the virus "Petya / Nyetya", which caused significant damage not only to business but also to the public sector, lost a lot of data and documents financial accounting for several periods. 
In the spring of 2016, the Decree of the President of Ukraine put into effect the decision of the National Security and Defense Council of 27.01.2016 and approved the "Cyber Security Strategy of Ukraine", the strategy was to create safe cyberspace and use such space in the interests of citizens, society and the state the strategy is still aimed at protecting the sphere of national defense.

In February 2017, the Decree of the President of Ukraine put into effect the decision of the National Security and Defense Council "On the doctrine of information security of citizens", which defines the priorities of state policy in the information sphere.

In autumn 2017, the Law of Ukraine "On Basic Principles of Cyber Security of Ukraine" came into force, which expanded and supplemented the provisions of the Cyber Security Strategy of Ukraine, approved by the Decree of the President of Ukraine.

Legal certainty in the legislation of information security areas was the beginning of active information security in Ukraine. For example, in December 2019, the State Service for Special Communications and Information Protection announced the creation of "Cyberpolygon" - a research complex, which was created under the auspices of the National Security and Defense Council and will operate based on the National Technical University of Ukraine "Igor Sikorsky Kyiv Polytechnic Institute".

The purpose of creating such a cyber range is to improve the skills and abilities of specialists in the field of cybersecurity, modeling of cyber threats, conducting cyber exercises.

The events, in particular, related to terrorist acts that lead to human casualties, are perceived by people as a personal tragedy. According to MV Through, any "loud" criminal offense, widely covered by the media and has great public resonance, has a negative psychological impact on the mass consciousness, creating an atmosphere of fear, apathy, insecurity of crime [36, 19].

Thus, the nature and effectiveness of the processes of information perception depend on the degree of completeness of knowledge, the system of formed orientations and attitudes, habits of the information behavior of the individual. Factors that determine the social status of the individual also play an important role. Information is perceived not by an abstract individual, but by a certain class, group representative. Therefore, the impact specifics on the formation of person's consciousness is that a person learns the norms, values of his/her social group, produces attitudes, and considers any information through the prism of these values and attitudes $[37,15]$.

Given the urgency of the problem of information security in modern Ukraine, no less important is the question of determining the form and methods of information 
security of citizens of Ukraine, which will be considered in this paper as a second thesis.

Ensuring information security is a set of measures taken by the state in the face of public authorities and aimed at achieving a state of protection of information of a person, society, and the state from information threats.

Information threats are a set of factors and conditions that cause the danger of violating information security (misinformation, false, untrue, etc.).

Ensuring information security is carried out through certain forms and methods that form a tool for the implementation of the whole set of measures to ensure the information rights, freedoms, and interests of citizens, society as a whole, and the state.

These tools should be based on the rule of law and form a high legal awareness of the subjects of the information process, which will form an idea of the consequences of their information and responsibility [38, 99-100].

Forms of information security are information patronage, information cooperation, and information confrontation [39].

Information patronage (from the Latin patronyms - defender) is a way to protect the information security of persons and legal entities), which are provided by the state. That is, this type involves the creation and provision of management bodies that collect information on information threats and those factors that destabilize the processing, exchange between management bodies and information security, and then provide information protection of persons subject to information security threats.

Information protection is provided by passing laws, providing judicial protection, conducting investigative (public and covert) investigative actions, and other forces and means carried out by law enforcement agencies. Collection and processing of necessary information carried out in the process of pre-trial investigation based on operational-search and operational-information activities [40, 51-52].

The second means of information security is information cooperation (from the Latin coopero - to cooperate), which is carried out between equivalent entities (physical, legal, international actors in the information process), to carry out multilevel actions aimed at obtaining information on possible threats and factors that destabilize protection against them by means specified by law.

Such methods and means include:

- Protection of the rights exercised by the judiciary to ensure the freedoms and interests of citizens related to information use;

- Ensuring administrative protection of the rights, freedoms, and interests of persons by territorial or departmental bodies; 
- Independent protection of rights, freedoms, and interests (personal, private, professional) secrets with the use of technical means of protection.

Ukraine cooperates with international organizations of security and secrecy, for example, between the company "Microsoft" and the state of Ukraine in the person of the State Service for Special Communications and Information Protection of Ukraine in December 2014 concluded the Government Security Program (Agreement on Security Cooperation). According to the terms of which Ukraine gets access to information about new cyber threats and sources of network attacks $[41,96]$.

Finally, the third form of information security is information confrontation, which is carried out between different entities (citizens, organizations, states), to search, store and process information of the enemy, as well as measures to protect their similar information from unauthorized or any other influence of the enemy.

This method of information protection is quite relevant for Ukraine, as the last 6 years in our country is the media psychological influence, both some national and foreign countries, as a result of which the entire Ukrainian information space is saturated with negative events resulting in increased anxiety among citizens. the number of criminal offenses committed by both citizens and foreigners [42, 93-97].

As already mentioned, information confrontation is carried out between different entities, which in turn has strong features, which further form certain types of information confrontation, such as:

- the information war is a complex impact on the information sphere of the rival country, which aims to persuade the opposite side to abandon the goals (political, economic, and other goals). This form of confrontation is aimed at consciousness and behavior of the audience (hostile, friendly, neutral) to achieve a certain goal;

- information terrorism is the active actions of certain subjects of criminal offenses, which are aimed at disrupting the information systems' work and communication networks, to inflict property damage, death, and other negative socially dangerous consequences. Such actions are accompanied by violation of public order and security, intimidation, to make decisions of public authorities; information terrorism can be committed with the help of information and psychological methods of influencing consciousness, as well as information and computer and electronic methods of influence;

- information crime is the commission of criminal offenses, both through the use of information and computer methods of influence and through information and psychological methods [43, p. 53-55].

Information security measures can be:

-passive - a system of administrative regime, program, legal measures that respond to existing information threats and counteract them; 
-active - measures aimed at preventing (clarifying the purpose, means) of information threats and counteracting them at the stage of their preparation [44, 132].

Given the above, to prevent violations of information rights, freedoms, and interests of citizens of Ukraine, including prevention of negative consequences of such violations, requires the active participation of the state in the development of information society and state information policy, with emphasis on it [45]:

- development and improvement of the system of formation of public opinion, comprehensive, objective informing of the population about the activities of state power, and government - about the processes of social development to prevent the possibility of influencing the consciousness of citizens through ignorance of situations;

- legal regulation of information relations and activities in society, improvement, and development of national legislation, effective mechanisms for its implementation, creation of institutions for the free receipt, use and dissemination of information as a basis for democratic development;

- creation of a single national information space as part of the world information space based on the national information and telecommunication structure.

According to the author, if the policy of information protection of citizens is based on these priorities, it is possible to reduce and further prevent the impact of information threats on the individual consciousness and psyche of citizens. After all, in real time it is not the protection of certain information itself that is relevant, but the protection against information.

Because the processes of protection of the psyche from information violence, especially a person, is characterized by the protection of the psyche and consciousness from dangerous information actions and depends on personal qualities and moral, social, legal norms in society [5, 132-134].

So, summarizing the above material, it should be noted that information security plays one of the most important roles in the ordinary citizens' lives and requires increased attention from the state through the introduction of certain mechanisms and institutions, with an extensive control system to prevent leakage, dissemination, and use of information. both personal citizens and organizations and the state.

This paper also explored the forms and methods of information security of citizens, such as information patronage, information cooperation, and information confrontation (both in general and in the form of information warfare, information terrorism, information crime) - however, according to the author, there is the problem is that these forms are the theoretical basis and require practical implementation in the current legislation of Ukraine, to prevent the commission of criminal offenses.

Given that the legislation does not contain regulations that will regulate the issues of information and psychological impact on citizens, the author recommends 
the Law of Ukraine "On Information Security of Citizens", which will determine the basics of information and psychological security of citizens, create a state system information and psychological security of citizens from the bodies and organizations of information and psychological security, as well as to determine in detail the factors and forms of negative consequences for entities that exercise and are subject to the information and psychological influence and responsibility for such influence.

If such a law is passed, it would be possible to warn:

- harm to human health, not only physical but also moral and the occurrence of negative consequences;

- information dependence syndrome;

- manipulation of public opinion;

- violation of important interests of citizens, society, and the state.

Also at the legislative level, there is a need to determine the main objectives of state policy in the field of information and psychological security of aperson the individual, because almost all regulations provide for information security of the state and create a system of information and psychological security, which will perform such functions as:

- identification and analysis of entities that exert psychological influence and control over their activities;

- monitoring of the main negative information and psychological influences that cause antisocial behavior;

- development and improvement of methods and ways of detection and neutralization of negative influences, rehabilitation of victims of such influences;

- creation of licensing, certification, and control bodies in the field of information and psychological security;

- informing the public about the activities of individuals, including organizations that violate the legislation on information and psychological security of citizens.

Also in such a law, it is necessary to define exceptional cases when it is allowed to use special means and methods of information and psychological influence, for example, "In case of emergencies, catastrophes, natural and man-made phenomena it is allowed to push ways and methods of information and psychological influence. consequences of such situations ", etc. At the same time, there should be a reservation that making changes to exceptional cases of information and psychological influence should be carried out exclusively by law.

Responsibility for violating the ban on the use of information and psychological influence should be defined both in the law "On information security of citizens of Ukraine" and the relevant articles of the Criminal Code of Ukraine (criminal liability for violating the ban on information and psychological influence on citizens, which 
entailed consequences), Code of Administrative Offenses, Civil Code of Ukraine and others.

It should be noted that such proposals for resolving the issue of information security concern the state. However, concerning the recommendation for citizens, an important means of counteracting information and psychological influence is selfdevelopment, improving their worldview, checking the information obtained in various sources, all information obtained in the media must be objectively questioned until such information is published in official sources.

\section{References:}

1. Rustamov Yu. Y. (2005) Rol USA v systeme mezhdunarodnыkh otnoshenyi: Zaochnыi dyaloh s Z. Bzhezynskym / Yusyf Rustamov; Nats. akad. nauk Azerbaidzhana, Yn-t fylosofyy y polytyko-pravovыkh yssled. - Baku: Elm,. [in Russian].

2. Bondarenko, V.O., \& Lytvynenko O.V. (1999) Informatsiina bezpeka suchasnoi derzhavy: kontseptualni rozdumy // Stratehichna panorama. № 1-2. - S. 127-133 [in Ukrainian].

3. Hnattsov O.H. Informatsiini resursy $v$ systemi zabezpechennia derzhavnoi bezpeky. www.niisp.gov.ua Retrieved from: http://www.niisp.gov.ua/vydanna/panorama [in Ukrainian].

4. Horban Yu. O. Informatsiina viina proty Ukrainy ta zasoby yii vedennia www.visnyk.academy. gov.ua Retrieved from: http://www.visnyk.academy. gov.ua/wpcontent/uploads/2015/04/20.pdf. [in Ukrainian].

5. Dzoban O.P., \& Pylypchuk V.H. (2011) Informatsiine nasylstvo ta bezpeka: svitohliadno-pravovi aspekty: Monohrafiia / Za zah. red. prof.. V.H. Pylypchuk: Kharkiv: Maidan [in Ukrainian].

6. Kormych B. A. (2007) Orhanizatsiino-pravovi zasady polityky informatsiinoi bezpeky Ukrainy [Tekst] : monohrafiia / B. A. Kormych. - Odesa : Yurydychna literatura [in Ukrainian].

7. Makarenko Ye. A. (2007) Yevropeiski komunikatsii: politychni, ekonomichni, pravovi, bezpekovi, dyplomatychni, suspilni ta kulturni aspekty : monohr. - K. : Tsentr vil. Presy [in Ukrainian].

8. Marutian R. R. Rekomendatsii shchodo vdoskonalennia polityky zabezpechennia informatsiinoi bezpeky Ukrainy http://www.dsaua.org Retrieved from http://www.dsaua.org/index.php?option=com_content\&view=article\&id=198\%3A2014-0813-12-55-48\&catid=66\%3A2010-12-13-08-48-53\&Itemid=90\&lang=uk; [in Ukrainian].

9. Medvid F. M. (2010) Informatsiina bezpeka Ukrainy: geneza i stanovlennia [Information security of Ukraine: genesis and formation] Naukovi pratsi MAUP - Scientific works of IAPM - K. : DP «Vyd. dim «Personal»,. -2(25). 116-122. [in Ukrainian].

10. Halamba M. \& Petryk V. Informatsiina bezpeka Ukrainy: poniattia, sutnist ta zahrozy. www.justinian.com.ua Retrievedn from http://www.justinian.com.ua [in Ukrainian].

11. Dzoban O.P. \& Pylypchuk V.H. (2011) Informatsiine nasylstvo ta bezpeka: svitohliadno-pravovi aspekty: Monohrafiia Kharkiv: Maidan

12. Samorukova O.L. (2017) Manipuliatyvni tekhnolohii u vysvitlenni zarubizhnymy ZMI sytuatsii v Ukraini Nauk. pr. Nats. b-ky Ukrainy im. V. I. Vernadskoho : zb. nauk. pr. / NAN Ukrainy, Nats. b-ka Ukrainy im. V. I. Vernadskoho, Asots. b-k Ukrainy. - Kyiv, 48, 351-359 [in Ukrainian].

13. Tolubka V. B. (2004) Informatsiina bezpeka derzhavy u konteksti protydii informatsiinym viinam: Navchalnyi posibnyk [Information security of the state in the context of counteracting information wars: Textbook] Kiev NAOU [in Ukrainian].

14. Hapeieva O. L. Diialnist ODKB u sferi informatsiinoi bezpeky [CSTO activities in the field of information security]. http://vim.gov.ua Retrieved from http://vim.gov.ua/index.php/ uk/ostannij-vipusk[in Ukrainian].

15. Zozulia O. S. (2015) Naukovyi dyskurs informatsiinoi bezpeky i priorytetni napriamy doslidzhennia v mezhakh spetsialnosti "Teoriia ta istoriia derzhavnoho upravlinnia". [Scientific discourse of information security and priority areas of research within the specialty "Theory and History of Public Administration"] http://pa.stateandregions.zp.ua Retrieved from http://pa.stateandregions.zp.ua/ archive/2_2015/11.pdf. 4[in Ukrainian]. 
16. Sosnin O.V. Informatsiina polityka Ukrainy: problemy rozbudovy [Information policy of Ukraine: problems of development] http://www.niisp.gov.ua Retrieved from http://www.niisp.gov.ua/vydanna/panorama[in Ukrainian].

17. Konstytutsiia Ukrainy (Vidomosti Verkhovnoi Rady Ukrainy (VVR), 1996, № 30, st. 141)» [Constitution of Ukraine (Bulletin of the Verkhovna Rada of Ukraine]. https://zakon.rada.gov.ua Retrieved from https://zakon.rada.gov.ua/laws/show/254\%D0\%BA/96-\%D0\%B2\%D1\%80\#Text [in Ukrainian].

18. Zakon Ukrainy «Pro Informatsiiu» [Law of Ukraine "On Information"]. https://zakon.rada.gov.ua Retrieved from https://zakon.rada.gov.ua/laws/show/2657-12\#Text[in Ukrainian].

19. Zakon Ukrainy «Pro drukovani zasoby informatsii» [Law of Ukraine "On printed media"]. https://zakon.rada.gov.ua Retrieved from https://zakon.rada.gov.ua/laws/show/2782-12\#Text[in Ukrainian].

20. Zakon Ukrainy «Pro telebachennia ta radiomovlennia» [Law of Ukraine "On Television and Radio Broadcasting"]. https://zakon.rada.gov.ua Retrieved from https://zakon.rada.gov.ua/laws/show/375912\#Text[in Ukrainian].

21. Zakon Ukrainy «Pro zakhyst informatsii v avtomatyzovanykh systemakh» [Law of Ukraine "On information protection in automated systems"] Rezhym dostupu: https://zakon.rada.gov.ua/laws/show/259415\#Text[in Ukrainian].

22. Ukaz Prezydenta Ukrainy «Pro Doktrynu informatsiinoi bezpeky Ukrainy» vid 08.07.2019 № 514/2009 [Decree of the President of Ukraine "On the Doctrine of Information Security of Ukraine"] https://zakon.rada.gov.ua Retrieved from https://zakon.rada.gov.ua/laws/show/514/2009\#Text[in Ukrainian].

23. Popov D.H. (2009) Protyvodeistvye nehatyvnomu ynformatsyonno-psykholohycheskomu vozdeistvyiu kak pidsystema obespechenyia bezopastnosty hosudarstva [Counteracting the negative information and psychological impact as a subsystem of state security] Yurydychsekaia psykholohyia-Legal psychology , 2, 18-22 [in Ukrainian].

24. Predmetnaia oblast sozdanyia y prymenenyia sredstv y mekhanyzmov ynformatsyonnoi bezopasnosty [Subject area of creation and application of information security tools and mechanisms] https://studfile.net Retrieved from https://studfile.net/preview/4238722/page:7/ [in Russian].

25. Tekhnycheskye sredstva fyksatsyy ynformatsyy [Technical means of fixing information] https://studopedia.ru Retrieved from https://studopedia.ru/3_135698_spetsialnoe-programmnoeobespechenie-po-zashchite.html [in Russian].

26. Rыbakova L.N. (2014) Lynyia zhyzny molodoho cheloveka: tsennostnue oryentatsyy y kopynhstratehyy [The life line of a young person: value orientations and coping strategies] Personal values: Sat. scientific. tr. int. scientific-practical seminar Personality in the modern world: to be or to seem? International Scientific Conference Dulatov Readings (Kostanai, 2014h.) 233-238 [in Russian].

27. Sorokyn, P. A. \& Chelovek (1992) Tsyvylyzatsyia. Obshchestvo [Person. Civilization. Society] Moscow: Polytyzdat,

28. Sukhnev V.Iu. (2009) Kontrol Ynterneta: tendentsyy y praktyka [Internet Control: Trends and Practice] Stratehyia Rossyy, № 2, 79-88. [in Russian].

29. Delo Varvarb Karaulovoi (2020) [The case of Varvara Karaulova] Vykypedyia.https://ru.wikipedia.org Rezhym dostupu https://ru.wikipedia.org/?oldid=106587796 (data obrashchenyia: 25.04.2020).

30. Orekhov V.V. (2015) Vplyv ZMI na stan natsionalnoi bezpeky Ukrainy [The influence of the media on the state of national security of Ukraine] Seriia: Sotsialni komunikatsii, 2 (22), 111-112. [in Ukrainian].

31. Torianyk V. M. (2016) Informatsiina bezpeka yak skladova natsionalnoi bezpeky derzhavy. Rol ZMI $\mathrm{v}$ zabezpechenni informatsiinoho suverenitetu Ukrainy [Information security as a component of national security. The role of the media in ensuring the information sovereignty of Ukraine] Pravo i suspilstvo, 2, 151-156 [in Ukrainian].

32. Mokriak M., (2017) Vplyv ZMI na determinatsiiu zlochynnosti [The influence of the media on the determination of crime] Kryminolohiia: Pidpryiemnytstvo, hospodarstvo, pravo. 11,195-198 [in Russian].

33. Sarkysov H. S. (1985) Obъekt yndyvydualnoho profylaktycheskoho vozdeistvyia v teoryy preduprezhdenyia prestupnosty [The object of individual preventive action in the theory of crime prevention] Erevan : Yzd-vo AN ArmSSR [in Russian].

34. Zahalnonatsionalne opytuvannia - Telebachennia, yak dzherelo politychnykh novyn. [Nationwide poll - Television as a source of political news] https://dif.org.ua Retrieved from https://dif.org.ua/article/telebachennya-yak-dzherelo-politichnikh-novin-zagalnonatsionalne-opituvannya [in Ukrainian].

35. Metodychni rekomendatsii, shchodo zdiisnennia protsesualnoho kerivnytstva dosudovym rozsliduvanniam terorystychnykh aktiv, skhvalenoho protokolom zasidannia naukovo-metodychnoi rady 
(2017) 4 https://mon.gov.ua Retrieved from https://mon.gov.ua/ua/osvita/visha-osvita/naukovo-metodichnarada-ministerstva-osviti-i-nauki-ukrayini [in Ukrainian].

36. Uzahalnennia statystychnykh ta analitychnykh danykh pro diialnist orhaniv prokuratury u 2018 rotsi. [Generalization of statistical and analytical data on the activities of the prosecutor's office in 2018.]. https://www.gp.gov.ua

Retrieved from https://www.gp.gov.ua/ua/vlada.html? m=publications\& $\mathrm{t}=\mathrm{rec} \& \mathrm{id}=248318$ [in Ukrainian].

37. Kroz, M.V. (2008) Krymynalnoe psykholohycheskoe vozdeistvye [Criminal psychological impact]Moscow: Yurlytynform [in Russian].

38. Chaldyny R. (2000) Psykholohyia vlyianyia [The psychology of influence] SPb.: Pyter [in Russian].

39. Lukianova V. (2013) Informatsiina bezpeka v umovakh rozvytku informatsiinykh system [Information security in minds development of information systems] Visnyk Khmelnytskoho natsionalnoho universytetu. Seriia: Ekonomichni nauky, 2. - T. 3, 97-101[in Ukrainian].

40. Zharkov Ya.M. \& Kompantseva L.F. (2012) Istoriia informatsiino-psykholohichnoho protyborstva: pidruch. [History of information-psychological anti-fight].-Kiev:Nauk.-vyd. viddil NASB Ukrainy [in Ukrainian].

41. Iudin O.K. \& Bohush V.M. (2004) Informatsiina bezpeka derzhavy. [State security information] Kharkiv: Konsum [in Ukrainian].

42. Liubokhynets L. S. (2017) Svitova praktyka zabezpechennia informatsiinoi bezpeky v suchasnomu hlobalizovanomu seredovyshchi [World practice of information security in today's globalized environment, 4-1 (43), 93-97[in Ukrainian].

43. Sidak V. S. (2013) Dyversyfikatsiia suspilnoi svidomosti - yak zahroza informatsiinii bezpetsi derzhavy ta yii neitralizatsiia [Diversification of public consciousness - as a threat to information security of the state and its neutralization] Efektyvna ekonomika, 8. http://www.economy.nayka.com.ua Retrieved from http://www.economy.nayka.com.ua/?op=1\&z=2219 [in Ukrainian].

44. Zlotnykova Z. Y. (2004) Proektnaia deiatelnost byblyotek kak faktor formyrovanyia sotsyalnokulturnoi sredы rehyona [ Library project activities as a factor in the formation of the socio-cultural environment of the region] Moskva [in Russian].

45. Krupnov A.E., Fynko O.A. \& Chereshkyn D.S.Hosudarstvennui komytet RF po sviazy y ynformatyzatsyy [State Committee of the Russian Federation for Communications and Informatization] http://emag.iis.ru Retrieved from http://emag.iis.ru/arc/infosoc/emag.nsf/BPA/8dcda61778b6f6c0c32568ab00577dd4[in Russian]. 